\title{
Maguai Songs Translation Based on Skopos Theory in Guangxi Zhuang Autonomous Region
}

\author{
Shixiang Liu \\ Department of Foreign Languages and Tourism \\ Hainan College of Software Technology \\ Qionghai, China
}

\author{
Bingyan Zhu* \\ Department of Foreign Languages and Tourism \\ Hainan College of Software Technology \\ Qionghai, China
}

\begin{abstract}
The Maguai Festival, also called the Frog Festival, is a traditional large-scale folk activity centered on frog worship among the Zhuang People in Guangxi Zhuang Autonomous Region, with the area Donglan, Bama, Fengshan, Tian'e, and Nandan around Guangxi's Hongshui River basin in particular. The rituals are mainly made up of four parts: looking for the Maguai, parading with Maguai coffin, worshiping the Maguai, and burying the Maguai. As the song contest continues through the whole sacrificial ceremony, so the Maguai Festival is also called the Maguai Songs Contest, which includes sacrificial ballads sung by sorcerers or other hosts to describe how the Maguai benefits the Zhuang People and antiphonal-styled singing to make friends or exhibit their talents. Taking the Maguai Songs among the Zhuang People in Guangxi Zhuang Autonomous Region as an example, the paper probes into Chinese-English translation strategies for song lyrics based on Skopos theory, which is of significance to arouse the motivation for attempts at folk song translation all over China.
\end{abstract}

Keywords - the Maguai songs; the Zhuang People in Guangxi Zhuang Autonomous Region; Chinese-English translation; Skopos theory

\section{INTRODUCTION}

The Hongshui River in the northeastern Guangxi Zhuang Autonomous Region is famous for its color, because it flows through the red sand-and-shell-containing rock formation. The Hongshui River breeds splendid cultures, one of the which is the Maguai Festival, set as a national intangible cultural heritage in 2006. The origin of the Maguai Festival goes as follows: a kind-hearted man named Donglin was always observing filial piety, and he wept so sadly after his mother's death. But the frogs outside were croaking all the time, which disturbed Donglin who used hot water to scald them, with countless frogs dead. And the Zhuang People suffered a severe drought and misfortunes one after another. And the god Muliujia (origin of all the females according to the Zhuang mythology) told them the fairies Maguai come from the heaven whose mother is the goddess of thunder who is responsible for rain. Donglin, who killed so many frogs, had to apologize and sent them to the heaven. Realizing everything, he felt regretful so deeply that he invited the living frogs to the village by sedan chair and buried the dead ones on the first day according to the Chinese lunar calendar, with Maguai songs sung through the sacrificial ceremony by thousands of people. From then on, the Maguai Festival served as a tradition among the Zhuang People.

\footnotetext{
*Corresponding author. Bingyan Zhu
}

In general, the festival is held for a month or so from the Chinese New Year to the end of the first month or the beginning of the second month of Chinese lunar calendar. Although the ceremony is kind of various, the rituals are broken into four parts: looking for Maguai, parading with Maguai coffin, worshiping Maguai, and burying Maguai [1].

\section{LITERATURE REVIEW}

The Zhuang People live on rice, which leads to the particular thoughts between thunder, rain, water, and rice, combing the frogs with the Zhuang People's production, life, and breeding. The spots to hold the Maguai Festival in Donglan County total more than 100, with that in Baying village in Bachou county being the grandest and the longest. As singing Maguai songs features the Maguai Festival in Baying village, it is also known as the Maguai Song Contest, which attracts a great many singers both from Donglan county and other counties, such as Tian'e, Fengshan, and Nanan county, with thousands of people. As the festival is more and more popular, a growing number of researchers from various universities or institutes pay closer attention to the event, such as Japan's Rikkyo University, Osaka University, France's National Center of Scientific Research, South China and IndoChina Peninsula Human Research Center, Panorama Co. Ltd. in Thailand, and Pacific International Communication Co. Ltd. In addition, the event has also been recorded and broadcast in various forms by CCTV and Guangxi TV. And experts and researchers from Thailand, Japan, France, Russia, Taiwan province, and Hongkong SAR have also covered and introduced it to other countries or regions [2].

The studies on the Maguai Festival can be summarized as follows: (1) The origin of the Maguai Festival. Song Guozhong holds the Maguai Festival, which serves as an old religious ritual, is associated with totem. The original Zhuang People, who wish to have a good harvest, treat frogs as the holy gods in charge of rain and thunder due to the low technology [3]. (2) The exploration of the Maguai Festival. Zeng Jieli and Luo Min argue that officials in charge should improve tourism facilities, encourage professional festival management company-leading market operation, explore gradually festivalrelated tourism development and operation scheme from the perspective of culture industry, and enhance the folk-custom tourism participation quality, while protecting and inheriting the traditional culture [4]. (3) The cultural value, social 
function and inheritance of the Maguai dance. Wei Lichun, Peng Danmei, and Luo Yingmei summarize that the Maguai dance not only contributes to body-building, entertainment and artistic esthetic, but also help to inherit national culture, enhance national cohesion, promote economic level, and further nationality sports culture development, etc., for which it is of great value to explore the Maguai dance in tourism with more investment [5]. (4) Case study of the Maguai Festival in Nadi. Qin Jinling concludes that the Maguai Festival in Nadi boasts an integrated bottom-up function, which enhances the social cohesion, collective identity and national identity, maintains the social order and stability. Bronze drums are used to show the status, power and wealth of chieftains and the elite, whom the Mogong serves heart and soul. During the Maguai Festival, people are able to remove the shackles of social hierarchy. In a way, the Maguai Festival has the function of social adjustment.With the chieftains' power breaking up, the status of Mogong declined, for which they began to serve the ordinary people [6]. (5) The protection and inheritance strategies for the Maguai Festival as ethnic national intangible heritage in Guangxi Autonomous Region. Xie Qiong and Chen Wei suppose that more measures should be taken to protect and inherit the Maguai Festival, such as how to play more roles from the government, how to publicize on a large scale, how to input more for the inheritor, and so on [7]. From the above mentioned studies, it can be concluded that no research related to the Maguai songs has been conducted, for which it is of significance to carry on more related studies to better spread intercultural communication.

\section{THE SKOPOS THEORY}

The skopos theory was raised in Possibilities and Limitations in Translation Criticism by athanrina Reiss in the 1970s. Ans skopos theory was raised in the co-authored General Foundation of Translation Theory with Hans.J. Vermeer, arguing that the translator should not be equivalent to the source language (short for SL thereafter) and its function, but the expected communicative one or more kinds of functions in the TL (short for TL thereafter) context in the whole translation process [8]. The theory was revised and termed Function plus Loyalty in the 1990s by Christiane Nord, with the emphasis focused on the different contexts for the SL and TL [8]. Nord holds that function serves as one of the most important factors that lead to what is expected from the translation in TL, but loyalty refers to the relation among the translator, the writer in SL, the reader in TL, and the translation initiator, which requires the translation not only to adhere to the content, culture, stylistics in SL [9], but also adjust the content and stylistics in SL to meet the needs of the reader in TL [9].

As is required by the skopos theory, the translator should make full analysis of the source text, taking different factors into account,and considering what in SL should be left, adjusted or adapted with proper translation strategies to ensure the translation in TL should be meaningful and readily accepted with the perfect combination of discourse and function for the expected functions. As a typical oral literature, the skopos theory is perfect for Chinese-English lyrics translation to create better discourse in SL which can intervene in the audience's thought and behavior [10]. On the other hand, it is necessary to learn and sing Chinese minority ethnic songs for a better understanding of the minority ethnic culture and boosting intercultural communication in the community full of minority customs.

\section{C-E LyRICS TRANSLATION STRATEGIES}

The Maguai Songs Contes includes sacrificial ballads sung by sorcerers or other hosts again and again and antiphonalstyled singing to make friends or exhibit their talents. Although the rhythm and tune many be kind of different, the lyrics are similar or almost the same, covering a wide range of topics, such as astronomy, geography, history, myths, daily life, agriculture, interpersonal relationship, etc. [2]. Incomplete statistics shows the number of the Maguai songs total 72 only in Nadong village, mainly in the form of antiphonal-styled singing with regard to the origin and merits and achievements of the Dragon King. After singing the Maguai songs for two hours, the participants can sing other kinds of songs.

\section{A. The Congratulation Song}

After finding the first frog, the Zhuang People play the gong and the drum, and set it in the community pavilion, sing the song named the Congratulation Song to describe how the frogs bring them good luck and harvest.

SL: 吉日接来蚂蛣娘, 良辰结缘蚂蛣郎。壮家人人爱天 女, 年年天女嫁壮乡。天地远隔千万里, 自有彩虹作桥 梁。吉日接来蚂蛣娘, 良辰结缘蚂蛣郎。

（廖明君、杨丹妮，壮族蚂蛣节，2014:57-58）

TL: On an auspicious day we welcome the lady maguai, for whom a perfect match is found; every Zhuang resident loves the fairy, who every year marries into the area; she might be far away from home, but there is a bridge made of the rainbow; on an auspicious day we welcome the lady maguai, for whom a perfect match is found.

(Liao Mingjun \& Yang Danni, The Maguai Festival of the Zhuang People, 2014:57-58)

1) Translating and transplanting cultural imagery: Cultural imagery, which is the combination of culture and image in a specific language community with relatively fixed connotation, associates the wisdom and the culture of different nations. It is a cultural symbol in a variety of forms, such as plants, animals, metaphors, figures, people's names, geographical terms, and so on. The word “娘”, “郎”, “良辰”, “吉日”, “结缘”, etc. in SL can lead to the image of wedding for Chinese readers. Cultural imagery redundancy refers to the image that is peculiar to a particular community. With no equivalent term in $\mathrm{TL}$, it is likely to lead to some misunderstanding or trouble in understanding even if translated literally, for which the translator should adhere to the needs of the target readers or audience with the strategy of loss or omission [11]. Therefore, the translator deleted the above mentioned words in TL to make the image of "the Mafuai" easier to understand for the readers in TL. 
2) Change of voice: Voice refers to the ways in which a language depicts the relationship between a verb and a noun phrase related to it, which can be divided into the active voice and the passive voice [12]. In accordance to the description in SL, the Maguai are fairies, with the god of thunder being her mother. That the Maguai are married to the Zhuang People is the will of the heaven, for which the passive voice should be used to whether to show tact or delicacy of sentiment or the cause is too obvious to be stated. It is advised that "marries into the area" should be changed to "are married here" for a better match between discourse and function.

3) Noun phrase translation: To change the default, adjust the template as follows. Whether they are endocentric phrases (e.g. cute girls), coordinate phrase (e.g. farmer and worker), or double-reference phrase (e.g. our capital city Beijing), it is supposed to be concise in translating. The noun phrases “壮家 人人” and “彩虹作桥梁” in SL should be translated properly to adapt to the habit and rhythm in TL. Therefore, it is advised to revise the above translation as follows.

On an auspicious day we welcome the lady maguai, for whom a perfect match is found; everyone in Zhuang People loves the fairies, who are married here year after year; they might be far away from home, but there is a rainbow bridge; on an auspicious day we welcome the lady maguai, for whom a perfect match is found.

\section{B. Congratulation of the Mother Frog}

When the parade is doing on, the Maguai song Congratulation of the Mother Frog (also named Best Wishes for Every Family) is sung, hoping the family are healthy, peasants have a good harvest, the elders enjoy longevity, and the children are intelligent.

SL: 主家洗耳听, 听我唱福歌, 新年新吉利, 你家大安 乐。养鸡成鸡种, 一月三十蛋。养狗成猎犬, 猪肉堆满 盘。养牛生龙角, 宝羊爬满破。养马能腾云, 骏骡配金 鞍。养鸟变金凤, 万事如心愿。种谷收金谷, 金谷堆满 仓。种棉收银花, 银花堆满箱。种茄茄块大, 一个三斤 三。种果得甜果, 甜得像蜜糖。种竹得竹笋, 竹笋高又 壮……别处没有云, 云绕你屋边; 别处没有雨, 雨落你家 田。云彩送绸缎, 雨水撒金钱。香的随便吃, 美的随意 穿, 蚂蛣赐吉利, 你家喜连连。

\section{（廖明君、杨丹妮，壮族蚂蛣节，2014:60）}

TL: Please listen to my singing, since I wish you the best things, prosperity for you in the New Year, who I believe will be happy and fair. Keep chickens and you will have many of them, which laid thirty eggs in one month; keep dogs and they will be good at hunting, you get so much pork that you can't finish eating; keep cows and they will even grow dragon-horns, keep sheep and they will be all over the mountain; keep horses and you will get one that can fly, mules you keep are equipped with gold saddle; keep birds and they all turn into phoenixes, all your wishes will become true; grow grains and you get golden ones, which are piled all over the barns; grow cotton and there will be silver cotton, which simply overfills everywhere; grow eggplants and you will get really big ones, each weighing there point three jin (about 1.65 kilogram); grow fruits and they are all sweet, so sweet that it tastes like honey; grow bamboos and you will get bamboo sprouts, which are all big and tall...Clouds are nowhere to be seen, because all of them get near to you; the rain falls nowhere else, because all goes to your fields; the clouds give you beautiful silks, while the rain brings you gold and money; you will eat delicious food, and wear really nice clothes, since the maguai makes you lucky, and your family will be forever happy.

(Liao Mingjun \& Yang Danni, The Maguai Festival of the Zhuang People, 2014:60)

1) Color words: Chinese and English Chinese color words bear different connotations due to cultural differences, for which appropriate strategies should be taken in translating the Chinese lyrics. The phrase “金鞍” in SL can be translated into “gold saddle", but “金谷” and “银花” in SL can not be translated word to word. As a matter of fact, the phrase “金谷” and “银花” in SL refers to good harvest when the rice and cotton are mature, not "golden ones" and "silver cotton" in SL. Therefore, it is imperative to adjust some contents to adapt to the style in TL for expected goals.

2) Figures of speech: To translate properly, adjust the figures of speech as follows.

a) Hyperbole: Hyperbole is to exaggeration as a rhetorical device to evoke strong feelings and create strong impressions with a certain image, function, feature, and degree magnified or minimized. In general, hyperbole is frequently used in some Chinese folk songs, due to which proper free translation should be taken when confronted with hyperbole. Hyperbole is used in the SL phrases “一个三斤三”, “养马能 腾云”, “养鸟变金风”, but they should not be translated literally if the aim of translation was born in mind.

b) Personification: Personification is to make something represent actions, qualities, feelings, etc. as human beings in art or literature. The phrases “云彩送绸缎” and “雨水撒金 钱” in SL belong to this type, which should be paid more attention to while translating.

c) Parallelism: Parallelism is two or more sentences, clauses, phrases, or words that bear the same grammatical structure and similar sentence pattern to improve readability. Parallelism is used from the sentence “养鸡成鸡种” to the last one, and translation should combine the meaning, form, and tone. Other figures of speech have also been adopted, but will not be described here. Therefore, the given translation above should be revised as follows:

Please listen to my song. Best wishes with prosperity in the New Year. Keep chickens and you will have many more, with thirty eggs each chicken in one month; keep dogs and they will be good at hunting; keep pigs and you will have a lot more pork on your plate; keep cattle and they will have dragon-horns; keep sheep and they will cover the whole mountain; keep horses and they can run faster, even your mules equipped with gold saddle; keep birds and they grow into more beautiful ones, making all your wishes come true; grow rice and they will fill all your barns; grow cotton and they will make all the boxes 
full; grow eggplants, each weighing one kilo and a half (about 1.65 kilogram); grow fruits and they are as sweet as honey; grow bamboos and you will get bamboo sprouts, big and tall...Clouds are nowhere to be seen except your house; the rain falls nowhere else except your fields; the clouds bring you beautiful silks, while the rain scatters gold and money; you can eat delicious food, get dressed prettily since the Maguai makes your family lucky and happy.

\section{Prayers}

The Zhuang sorcerer and the host will sing prayers for the frogs, describing their origin and merits and telling people to respect and love frogs, with the aim of a good harvest in the coming year.

SL: 前世传古道, 蚂蛣本是神仙变, 帮助凡间把福造。 蚂蛣原住雷乱塘, 日夜欢乐叫声高。有个女人叫牙游, 她 嫌吵声刺耳难睡觉, 她用牛锅把水煮, 她用鼎锅把水烧, 锅锅滚水塘里倒, 大小蚂蛣塘面漂, 侥幸活着上天去, 玉 帝面前把状告。天上玉帝听得说, 圣旨降下凡间道: 正月 初一二月初, 祭葬蚂蛣同吊孝, 人畜平安百业旺, 风调雨 顺收成好, 若还与天相对抗, 有病有灾莫懊恼。从此设立 蚂蛣节, 代代都把蚂蛣保, 年年天峒冰洌洌, 年年河湖水 滔滔, 五谷丰登黄澄澄, 无灾无难乐陶陶。

\section{（廖明君、杨丹妮，壮族蚂蛣节，2014:61）}

TL: Ancestors passed on to us this story, the maguai used to be a fairy, which brought the mortals happiness; it originally lived in Leiluan Pool, it happily croaked day and night, but a woman called Yayou, couldn't sleep because of the croak, in a big pot she boiled water, as well as in a tripod caldron, then she poured it into the pool, on which dead maguais floated, those still alive went to the heaven, and complained to the Jade Emperor, who after hearing the complaints, immediately sent out an imperial order: From the New Year's first day to the early second month of the Chinese lunar calendar, sacrifice should be offered to maguais as it is done to parents, in this way all humans and animals will live happily, also come fine weather and good harvest, but if you humans work against it, don't worry about mishap and illness, just start a Maguai Festival for it, for generations the maguai must be protected, then every year rainfall will be guaranteed, the harvest is so good that you can't imagine it, and there is no misfortune but only happiness.

(Liao Mingjun \& Yang Danni, The Maguai Festival of the Zhuang People, 2014:61)

1) Rhyming words: Rhyme is repetition of similarsounding or the same-sounding words, most often in the final syllables of lines in poems and songs to make it pleasant to hear. The following words “道”, “造”, “高”, “觉”, “觉”, “倒”, “漂”, “告”, “孝”, “好”, “恼”, “保”, “滔” with the rime “ao” in SL repeated. Therefore, the readability in pronunciation should be taken into account to facilitate understanding for TL readers while conforming to the original style.

2) Reduplicative words: Reduplicative words are the words that are reused, with the forms "AA", "AAB", "ABB", "AABB", "AABC", "ABCC", and "ABAC" frequently used in Chinese. To use reduplicative words in a proper way can make the description more vivid and attractive. The reduplicative words “洌洌”, “滔滔”, “澄澄”, and “陶陶” in SL have been adopted to express the Zhuang People's gratitude for the frogs. But the reduplicative words can not be translated word to word to achieve the expected objectives.

3) Singular and plural form conversion from Chinese to English: Although there is singular or plural form in Chinese logically, the nouns bear no distinguishing mark in a particular from. In the process of Chinese-English translation, the conversion should be taken if the meaning, part of speech, or the number of some words in $\mathrm{TL}$ cannot cover the corresponding part of that in SL [13]. Obviously, the phrases “蚂蛣”, “神仙”, “凡间” in SL refer to a lot of frogs, fairies, and people in Chinese, but some misunderstanding has resulted from the above translation with “蚂蛣” and “神仙” in singular form. Therefore, the translation can be revised as following.

Ancestors passed on to us (that), the maguai used to be fairies, who brought happiness for mortals; they originally lived in Leiluan Pool, gayly croaking day and night; they disturbed a woman called Yayou, she boiled water in huge pots and poured into the pool, on which dead bodies floated; those still alive went to the heaven and filed a suit to the Jade Emperor, who immediately issued an imperial edict: From the New Year's first day to the early of the second month according to the Chinese lunar calendar, sacrifice should be offered to maguai as it is done to the dead; this can make all humans and animals live happily, together with fine weather and good harvest; if our humans still work against it, misfortune and illness will come along; we establish the Maguai Festival to protect them, we will be blessed with enough rainfall, good harvest and happiness, with no misfortune to us all.

\section{CONCLUSION}

The Maguai songs are the Zhuang People's folk literature endemic to Guangxi Hongshuihe river basin, consisting of the Zhuang People's knowledge and folk wisdom in dealing with nature, people, and society. They are rich cultural heritage with high artistic value, but Chinese-English translation related research is extremely scarce. Therefore, it is of great value to carry on related research to display minority folk literature in the context of the charming Chinese multi-culture, widely spread ethnic art around the world, and promote international communication, because what is unique in one nation is more likely to be well-known in the world.

\section{REFERENCES}

[1] Qin Yisheng. Survey and Study on the Maguai Festival in Donglan county, Guangxi, Study of Ethnics in Guangxi, vol. 2, 1999, pp. 70-74.

[2] Liao Mingjun and Yang Danni. The Maguai Festival of the Zhuang People. Hefei, Anhui: Anhui People's Press, 2015.

[3] Song Guozhong. Primitive witchcraft and national character Study on the Maguai Festival of the Zhuang People, Study of Ethnics in Guangxi, vol. 2, 1992, pp. 80-86. 
[4] Zeng Jieli and Luo Min. Ethnic festival operation from the perspective of cultural industry development, Social scientist, vol. 6, 2008, pp. 108110 .

[5] Wei Lichun, Peng Danmei, and Luo Yingmei. The Cultural social function of the Maguai dance of Chuang and resources development in Red River Basin, Journal of Hebei Institute of Physical Education, vol. 22, 2008, pp. 89-91.

[6] Qin Jinling. A study on the Maguai Festival of Zhuang Nationality in Nadi. Nanning, Guangxi: Guangxi University for nationalities, 2015.

[7] Xie Qiong and Chen Wei. On the protection and inheritance of ethnic intangible cultural heritage in Guangxi autonomous region, Journal of Baise University, vol. 21, 2008, pp. 107-111.

[8] Nord, Christiane. "Text analysis in translator training" in Teaching Translation and Interpreting: Training, Talent and Experience, Cay Dollerup and Anne Loddegaard, Eds. Amsterdam/Philadelphia: John Benjamins, 1992, pp. 39-48.

[9] Nord, Christiane.Translating as a purposeful Activity: Functionalist Approaches Explained. Shanghai: Shanghai Foreign Language Education Press, 2001.

[10] Chen Xiaowei. The rhetoric reflection of the German skopos theory, Foreign languages research, vol. 131, 2012, pp. 91-95.

[11] Shixiang Liu and Bingyan Zhu. "Translating and Transplanting Cultural Imagery in Tourism Texts Taking Hainan International Tourist Destination as an Example," in Lecture Notes in Management Science, vol. 47, Harry Zhang, Ed. Singapore: Singapore Management and Sports Science Institute, 2015, pp.202-206.

[12] J.C. Richards, S. Richard, K. Heidi, and K. Youngkyu. Longman Dictionary of Language Teaching and Applied Linguistics, 3rd ed., Beijing, China: Foreign Language Teaching and Research Press, 2005.

[13] Xiong Wenhua. Comparing the devices in singular and plural form between Chinese and English, Language teaching and linguistic studies, vol. 2, 1988, pp. 131-143. 